\title{
MITIGATION OF CLIMATE CHANGE ADVERSE EFFECT BY ACCELERATING FENNEL GROWTH AND FLOWERING
}

\author{
Salwa S.S. Awad Alla and Soad M.M. Salem \\ Department of Medicinal and Aromatic Plants, Agricultural Research Center, Dokii, Egypt.
}

\begin{abstract}
The present experiment was conducted during 2014/2015 and 2015/2016 seasons in the Farm of Medicinal and Aromatic Plants Research Department in El Kanater El Khairia, Egypt to study the effect of ascorbic acid (AA) and citric acid (CA) individually and in combination on Foeniculum vulgare var. vulgare plants, in order to alleiviate climate change adverse effect by induce early flowering and to stimulate the growth and yield. Ascorbic acid and citric acid were sprayed at two rates 100 and $200 \mathrm{ppm}$.
\end{abstract}

The following results were recorded: In general, Indian fennel plants were significantly responded to ascorbic and citric acid. Ascorbic acid at 100 and $200 \mathrm{ppm}$ and citric acid at 200ppm increased the vegetative growth (plant height and number of branches/plant), number of umbels/plant, fruit yield/plant and essential oil production. Ascorbic and Citric acid each of them at 100 and $200 \mathrm{ppm}$ decreased the time to flowering, this means that, the antioxidant ascorbic and

Scientific J. Flowers \& Ornamental Plants, 3(3):177-191 (2016).

Received:

$1 / 9 / 2016$

Revised by:

Prof. Dr. M.S. Hanafy, Cairo Univ.

Prof. Dr. I.M.A. Haridy, Hort. Res. Inst., ARC.

citric acid stimulating fennel growth, shortening the juvenility stage and induce early flowering. The treated plants by the combination of ascorbic and citric acid at 200ppm gave the highest vegetative growth (plant height and number of branches/plant), number of umbels/plant, fruit yield/plant, essential oil production and accelerating flowering by 27 days in the $1^{\text {st }}$ season and 22 day in the $2^{\text {nd }}$ one in comparison with control. Ascorbic acid at $200 \mathrm{ppm}$ plus CA at $200 \mathrm{ppm}$ gave the highest anethole content and the lowest fenchone. Ascorbic acid at $200 \mathrm{ppm}$ with CA at $200 \mathrm{ppm}$ produced the least time to flowering. The application of the combination of ascorbic and citric acid at the highest rate $200 \mathrm{ppm}$ had a promotion effect in growth traits and inducing early flowering, therefore accelerating fruiting of fennel plants before the sharp fluctuations of climate that occurred in the spring which in turn had a bad effect in fruiting of umbelliferous plants.

Key words: fennel, Foeniculum vulgare var. vulgare, ascorbic acid, citric acid, anethole.

\section{INTRODUCTION}

Global climate change is known as one of the greatest challenges to the humankind and all other life forms on Earth. Climate change may not currently represent the biggest threat to medicinal plants, but it has the potential to become a much greater threat in future decades. Climate changes have effect on medicinal plants and can affect secondary metabolites and other compounds that plants produce, and these in effect could impact on their medicinal activity. Flowering and fruiting phenology of plants sensitive to environmental as temperature (Mahdi et al., 2011), so this research aim to shorten the period of growth and induce early flowering of fennel plants to avoid the adverse effect of climate change, as temperature rise during the fruiting stage in spring season. 
Some studies have demonstrated that temperature stress can affect the secondary metabolites and other compounds that plants produce and these are usually the basis for their activities (Dobhal et al., 2004).

Indian fennel (Foeniculum vulgare var. vulgare) is a plant belonging to the Family Apiaceae (Umbelliferae) having medicinal properties as antispasmodic, appetite stimulant, stomachic, diuretic, antiinflammatory, anti-diarrheic, against colic and as a lactation promoter. Fennel seed which are used as flavouring agents in packed goods, meat, ice creams and alcoholic beverages, etc. due to their characteristic anise odour (Diaaz-Maroto et al., 2006). Several components of the essential oil from this plant have important applications, anethole is used for flavoring agent in perfumery in cosmetics, in soap and pharmaceutical aid (flavor), fenchone is used as counterritant, limonene is used as solvent, resins, wetting and dispersing agent and apinene used in manufacture of camphor, insecticides, solvents, perfume bases (Marotti et al., 1993; Piccaglia and Marotti et al., 1993 and Cavaleiro et al., 1993).

Ascorbic acid (Vitamin C) is synthesized in the higher plants and influences plant growth and development and plays an important role in the electron transport system (El-Kobisy et al., 2005). Blokhina et al. (2003) reported that ascorbic acid can be a regulator on cell division and differentiation and has an important role in a wide range of functions such as antioxidant defense, regulation of photosynthesis and growth. Ascorbic acid is a cofactor for many enzymes such as ones involved in the cell wall synthesis and hydroxylation of proline residues (Ishikawa et al., 2006). Abdel Aziz et al. (2009) pointed that growth and flowering of gladiolus was affected by ascorbic acid at 100 or $200 \mathrm{ppm}$. Hendawy and Ezz El-Din (2010) indicated that ascorbic acid gave the best values of plant height, number of branches, number of flower heads and seed weight per plant in fennel.
Hanafy Ahmed (1996) on lettuce and Tarraf et al. (1999) on lemongrass they found that (AA) had positive effect on growth parameters. Furthermore, the endogenous level of ascorbic acid (AA) play a role in floral induction that it has recently been suggested to be important in the regulation of developmental senescence. Kotchoni et al. (2009) suggested that ascorbic acid act as an endogenous signal to influence the flowering time by modulating the related gene expression and metabolism process.

The role of AA in controlling flowering and senescence due to its essential function as a co-factor for the biosynthesis of GA and ABA, ascorbic acid appears to influence not only the endogenous level but also signaling of these plant hormones, and thus affect developmental flowering and senescence in a presumably photoperiod. Other hormones such as SA (and ethylene) may also be affected by AA. In addition, the redox status of AA may play a role in signaling in this interconnected phytohormone network. However, there are obviously still large gaps to fill in order to elucidate the precise role of AA in regulating the final stages of plant development (Carina et al., 2006).

Citric acid (CA) is a six carbon organic acid, having a central role in CA cycle in mitochondria that creates cellular energy by phosphorylative oxidation reactions. It is created by addition of acetyle-CoA to oxaloacetic acid that is converted to succinate and malate in next steps (Wills et al., 1981).

Endogenous organic acids such as citric acid (CA) are the source of both carbon and energy for cells and are used in the respiratory cycle and other biochemical pathways therefore, they can influence the flowers (Silva, 2003).

The aim of this work was to study the influence of ascorbic acid and citric acid and their combination to alleviate the adverse effect of climate change on fennel plant by stimulating the growth, induce early 
flowering and fruiting consequently raising fruit yield as well as volatile oil.

\section{MATERIALS AND METHODS}

This study was carried out at two seasons 2014/2015 and 2015/2016 in the Experimental Farm of Medicinal and Aromatic Plants Research Department in El Kanater El Khairia, Egypt.

The fruits of Indian fennel (Foeniculum vulgare var. vulgare) were sown on $5^{\text {th }}$ November in the field at a distance of $30 \mathrm{~cm}$ between hills and $60 \mathrm{~cm}$ between rows in both seasons.

The plants were sprayed (three times in the two seasons) with ascorbic acid (AA) and citric acid (CA) at concentrations of 100 and $200 \mathrm{ppm}$ each of them solely and in combination. Spraying was done 30 days from sowing and repeated at 30 day intervals for the $2^{\text {nd }}$ and $3^{\text {rd }}$.

The experiment included the following treatments:

1- Control.

2- Ascorbic acid $\left(\mathrm{AA}_{1}\right)$ 100ppm.

3- Ascorbic acid $\left(\mathrm{AA}_{2}\right)$ 200ppm.

4- Citric acid $\left(\mathrm{CA}_{1}\right)$ 100ppm.

5- Citric acid $\left(\mathrm{CA}_{2}\right)$ 200ppm.

6- $\left(\mathrm{AA}_{1}\right) 100 \mathrm{ppm}+\left(\mathrm{CA}_{1}\right) 100 \mathrm{ppm}$.

7- $\left(\mathrm{AA}_{1}\right) 100 \mathrm{ppm}+\left(\mathrm{CA}_{2}\right) 100 \mathrm{ppm}$.

8- $\left(\mathrm{AA}_{2}\right) 200 \mathrm{ppm}+\left(\mathrm{CA}_{1}\right) 100 \mathrm{ppm}$.

9- $\left(\mathrm{AA}_{2}\right) 200 \mathrm{ppm}+\left(\mathrm{CA}_{2}\right)$ 100ppm.

NPK fertilizers were added at the recommended level $\left(45 \mathrm{P}_{2} \mathrm{O}_{5}, 60 \mathrm{~N}\right.$ and 48 $\left.\mathrm{K}_{2} \mathrm{O} \mathrm{kg} / \mathrm{fed}\right)$ in three doses, the $1^{\text {st }}$ was for all phosphorous amount which was added during soil preparation, the rest (NK) were applied in two equal doses the $1^{\text {st }}$ was applied 30 days after sowing, the second was added 30 days later.

The following data were recorded:

- Plant height $(\mathrm{cm})$.

- Number of branches/plant.
- Flowering time from sowing date.

- Number of umbels/plant.

- Fruit yield g/plant.

- Volatile oil percentage was determined according to (British Pharmacopeia, 1963).

- Volatile oil yield (ml/plant).

- Chemical composition of Volatile oil (GLC) analysis as recommended by (Hoftman, 1967; Bunzen et al., 1969).

\section{Experiment layout:}

The experiment layout was designed in complete randomized blocks included nine treatments each treatment was replicated three times and each replicate consisted of 15 plant. The recorded data were statistically analyzed according to (Snedecor and Conchran, 1980) mean of the treatments were compared using LSD at 5\%.

\section{RESULTS AND DISCUSSION}

\section{Effect of ascorbic and citric acid on vegetative growth:}

Data on vegetative growth revealed that treatments of ascorbic (AA) and citric acid (CA) each alone or in combinations significantly increased all the vegetative growth characters of Indian fennel plant in the two seasons.

\section{Plant height (cm/plant):}

Data in Table (1) showed that, ascorbic acid and citric acid each of them alone or in combination significantly increased the plant height $(\mathrm{cm}) /$ plant compared to the control in both seasons.

Data emphasized that, the two rates of ascorbic acid (100 and 200 ppm) had a highly significant effect on plant height in both seasons. Ascorbic acid at the two rates produced the tallest plants, values were (170.0 and $173.0 \mathrm{~cm} /$ plant) in the first season and $(169.8$ and $1171.7 \mathrm{~cm} /$ plant $)$ in the second one compared to the control.

Also, it could be observed that in the first season the two rates 100 and 200 ppm of citric acid significantly increased plant 
Table 1. Effect of ascorbic acid and citric acid on vegetative growth of Foeniculum vulgare var. vulgare plants.

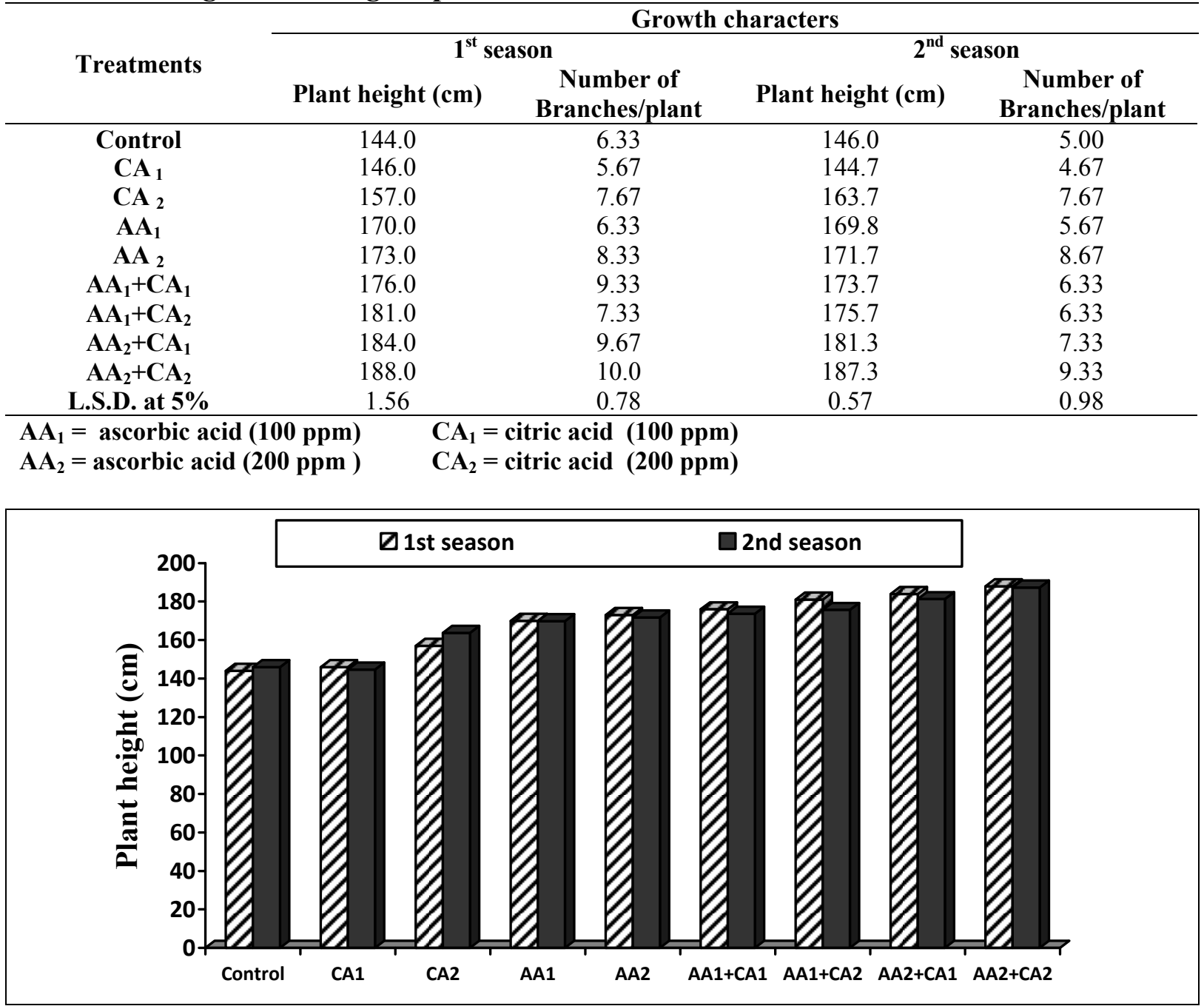

Fig. 1. Effect of ascorbic and citric acid on plant height of Foeniculum vulgare var. vulgare plants.

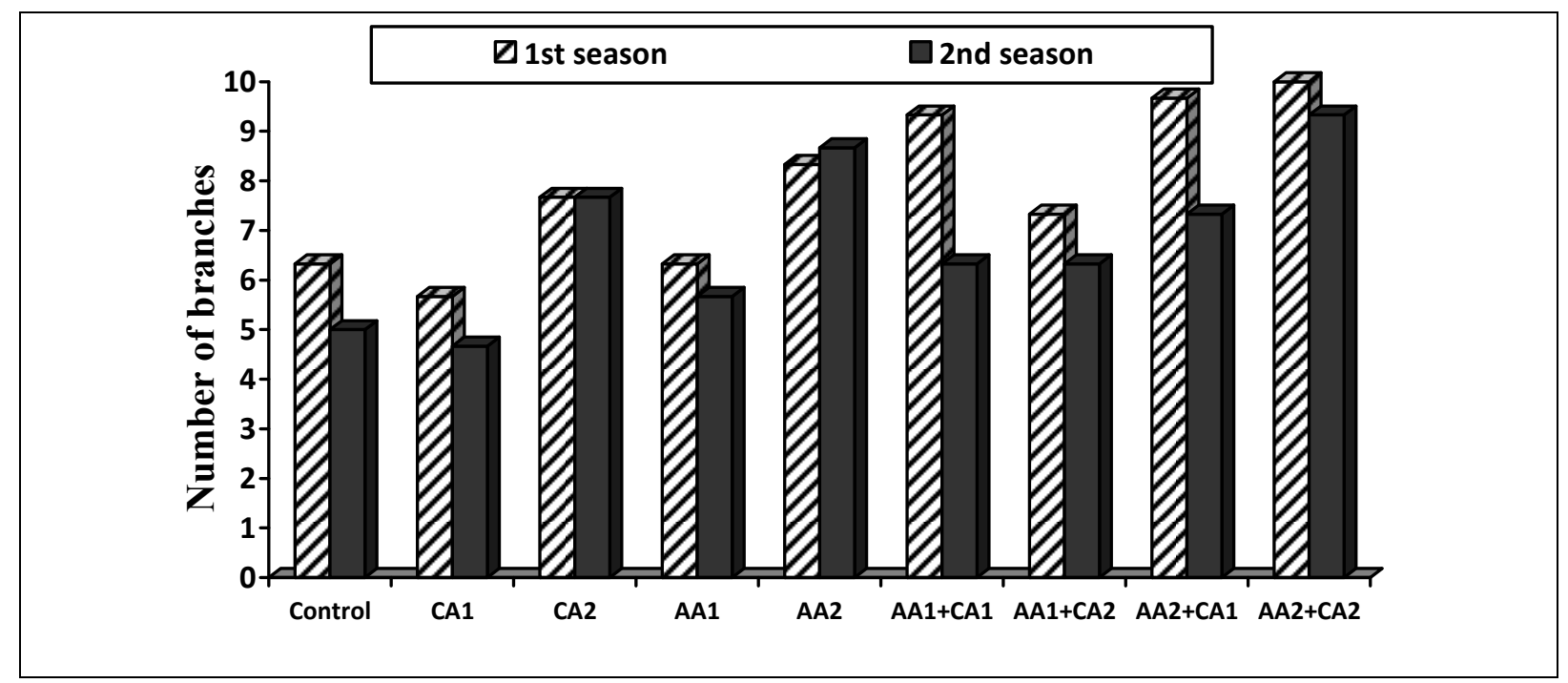

Fig. 2. Effect of ascorbic and citric acid on number of branches of Foeniculum vulgare var. vulgare plants 
height (146.0 and $157.0 \mathrm{~cm} /$ plant) compared to the control $(144.0 \mathrm{~cm} / \mathrm{plant})$, but in the second season only the highest rate of citric acid $200 \mathrm{ppm}$ increased plant height was $(163.7 \mathrm{~cm} /$ plant $)$ compared to the control $(146.0 \mathrm{~cm} /$ plant $)$.

Concerning the effect of the interaction between ascorbic acid (AA) and citric acid (CA) treatments data revealed that, growth of fennel showed a stimulation effect in response to all interaction treatments. It was also noticed that, the interaction treatment ascorbic acid (200 ppm) and citric acid (200 ppm) was found to be the most effective treatment in this respect, this result hold true in the two seasons. Plants of this treatment were the tallest ones and attained (188.0 and $187.3 \mathrm{~cm} \mathrm{/plant})$ in front of $(144.0$ and $146.0 \mathrm{~cm} /$ plant) for the control plants in the first and the second season, respectively.

\section{Number of branches/plant):}

Regarding the effect of ascorbic acid (AA) on the number of branches/plant Table (1), it was found that (AA) at $200 \mathrm{ppm}$ gave highly significant increase in this respect. The values were 8.33 and 8.67 branches/plant compared to the control 6.33 and 5.00 branches/plant in the first and second season, respectively. Ascorbic acid (AA) is currently considered to be regulate plant growth and development owing to its effects on cell division and differentiation. The mechanism for ascorbate regulation of plant growth and development may reside in its interaction with phytohormones. Ascorbate is cofactor for biosynthesis of several phytohormones such as ethylene, gibberellins (GA) and abscisic acid (ABA). Ascorbate in plants could regulate the growth through interaction with phytohormones (Pastori et al., 2003). These results were in conformity with those reported by (El-Gabas, 2006) found that spraying ascorbic had favorable effects on growth characters of sunflower. Similar results were obtained by (El-Zohiri, 2009) on globe artichoke found that foliar application of salicylic acid or ascorbic acid had a positive effect on vegetative growth. Another experiment showed that application of ascorbic acid increased vegetative growth and chemical components of Cupressus sempervirens L. plants (Farahat et al., 2007). A report illustrated that ascorbic acid affected on the growth and some chemical compounds of Hibiscus rosa sineses (ElQuesni et al., 2009). Also, ascorbic acid significantly effect on growth of German chamomile (Bahram et al., 2014).

The results presented in Table (1) showed that in both seasons, treating the plants with citric acid (CA) 200 ppm promoted the branching of fennel plants and resulted 7.67 branches/plant compared to the control 6.33 and 5.00 branches/plant in the two seasons, respectively. These results were found to be in agreement with (Mirzajani, 2013) on Ocimum basilicum L. and (Jaafari and Hadvi, 2012) citric acid increased the growth of basil plants and (Jafari and Hadavi, 2012) on dill plants.

As for combination treatments of ascorbic acid and citric acid, it was noticed that India fennel growth showed a promotion effect due to combination treatments at all rates, values of branches number were significantly higher than those of the individual treatments and control in the two seasons. Moreover, the highest response was obtained in case of (AA) 200 ppm plus (CA) at $200 \mathrm{ppm}$. Plants of this treatment produced the highest values of branches/plant 10.00 and 9.33 branches/plant in the $1^{\text {st }}$ and $2^{\text {nd }}$ season, respectively.

\section{Effect of ascorbic and citric acid on flowering:}

\section{Flowering time from sowing date:}

Table (2) showed that a significant effect in inducing early flowering and reduction the time to flowering in fennel plants as a result of the application of AA and CA each of them solely or in combination in the two seasons.

Results pointed out that, spraying (AA) at 100 and $200 \mathrm{ppm}$ significantly reduced the 
Table 2. Effect of ascorbic acid and citric acid on flowering of Foeniculum vulgare var. vulgare plants.

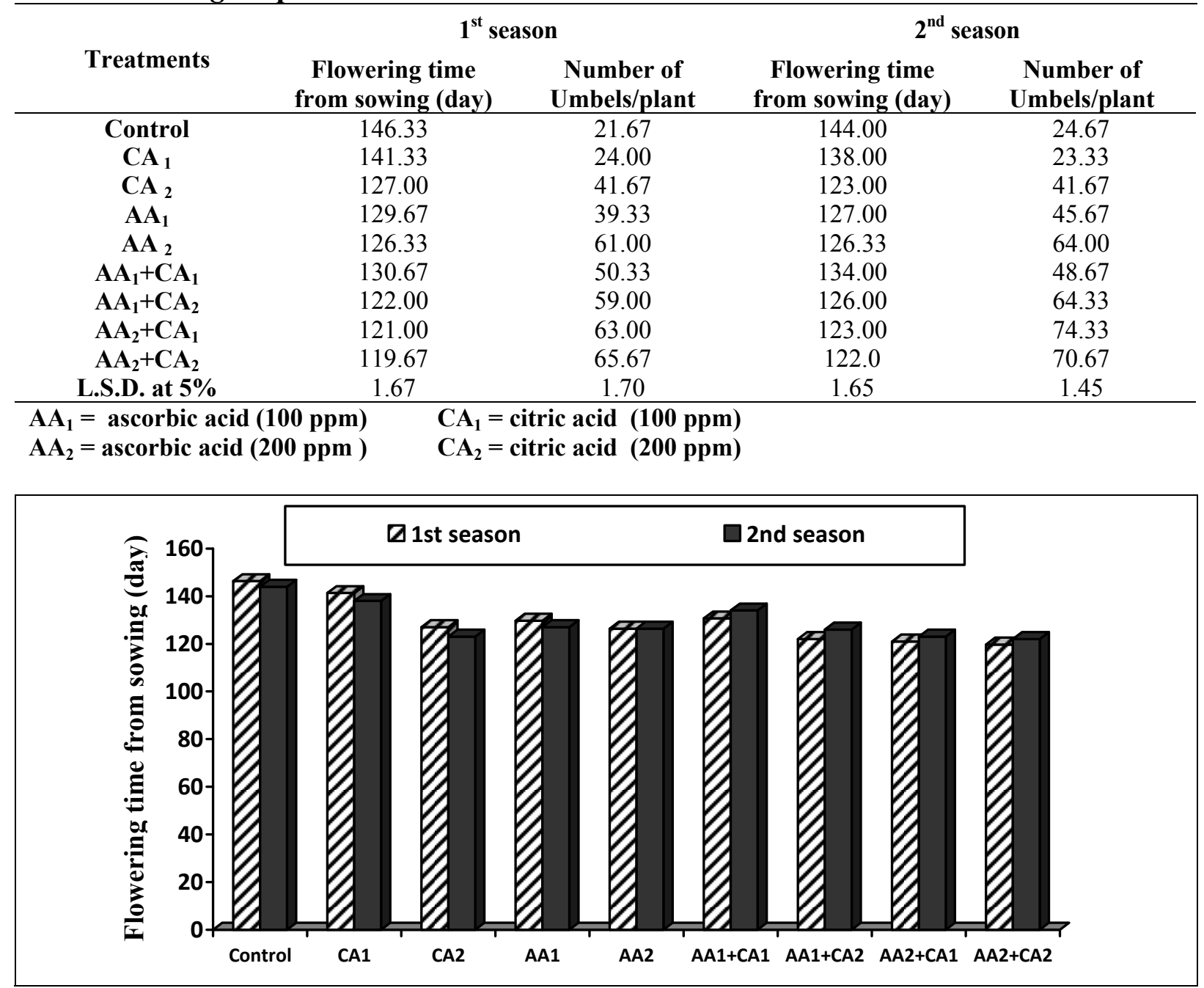

Fig. 3. Effect of ascorbic and citric acid on flowering time from sowing (day) of Foeniculum vulgare var. vulgare plants.

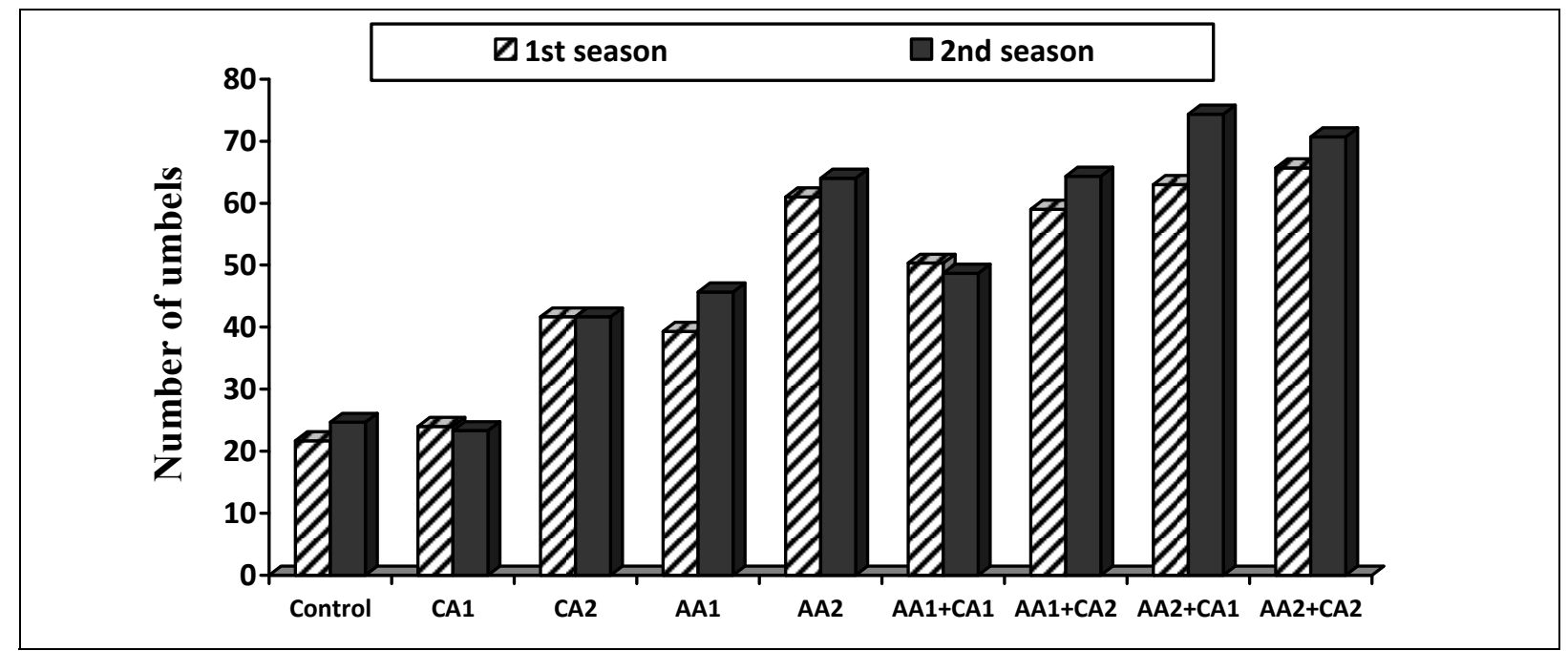

Fig. 4. Effect of ascorbic acid and citric acid on number of umbelsof Foeniculum vulgare var. vulgare plants. 
flowering time from sowing date. Indian fennel plants started to flower after 129.67 and 126.33 days from sowing date compared to control plants that began to flower after 146.33 days in the first season, also in the second season the plants start to flower after 127.00 and 126.33 days compared the control 144.00 days.

In the same way, early flowering was occurred in fennel plants which sprayed with citric acid (CA) at 100 and $200 \mathrm{ppm}$, the plants started to flower after 141.33 and 127.00 day from sowing compared to 146.33 day in the control in the first season, also in the second season plants started to flower after 138.00 and 123.00 day compared to the control 144.00 days.

Regarding the combination treatments, ascorbic and citric acid at all rates significantly reduced the flowering time compared to each of them alone and the control. The shortest flowering time from sowing date was noticed in plants sprayed by ascorbic acid at $200 \mathrm{ppm}$ combined with citric acid at $200 \mathrm{ppm}$. The flowering time from sowing was 119.67 days compared to 146.33 days in the control in the first season, and 122.00 days compared to in the control 144.00 days in the second one.

On the light of these results, it could be concluded that, the antioxidant ascorbic and citric acid have a beneficial effect on accelerating flowering in fennel plants, positive results were obtained by using both of ascorbic and citric solely and combination. The highest response was obtained by using the combination between the two antioxidants at the high level. The shortest time to flowering was 119.67 and 122.00 days with a reduction of about 26.7 and 22 days to flowering for the $1^{\text {st }}$ and $2^{\text {nd }}$ season respects as shown in Table (2).

These results were found to be in harmony with those of (Kotchoni et al., 2009) suggested that ascorbic acid act as an endogenous signal to influence the flowering time by modulating the related gene expression and metabolism process. (ElZohiri, 2009) on globe artichoke it was found that foliar application of salicylic acid or ascorbic acid resulted in the highest increments on early yield. And (Silva, 2003) that suggested citric acid (CA) are the source of both carbon and energy for cells and are used in the respiratory cycle and other biochemical pathways therefore, they can influence the flowers.

\section{Number of umbels/plant:}

Data in Table (2) indicated that, the number of umbels/plant were considerably affected by ascorbic and citric acid reflecting their stimulating effect on growth of Indian fennel, the results could be discussed as follow:

Concerning the effect of ascorbic acid (AA), data in Table (2) revealed that the two rates 100 and $200 \mathrm{ppm}$ significantly increased the number of umbels/plant over the control in both seasons. The values were 39.33 and 61.00 umbels/plant for 100 and $200 \mathrm{ppm}$ compared to 21.67 umbels/plant in the untreated plants in the first season. In the second season, values were 45.67 and 64.00 umbels/plant compared to untreated plants 24.67 of umbels/plant.

It could be noticed that, a significant increase in the number of umbels/plant due to spraying fennel plants by citric acid (CA) at $200 \mathrm{ppm}$ compared to the control in the two seasons. The values were 41.67 and 41.67 umbels/plant in front of 21.67 and 24.67 umbels/plant in the first and the second season, respectively. These results were in agreement with (Jaafari and Hadvi, 2012).

Combined treatments of ascorbic and citric acid at all rates, showed high significant increase in the number of umbels/plant in the two seasons. The greatest number of umbels/plant was 65.67 umbels/plant by using ascorbic acid (AA) at $200 \mathrm{ppm}$ plus citric acid at $200 \mathrm{ppm}$ in the first season. While, in the second season the greatest umbels number/plant occurred was 
74.33 umbels/plant in case of ascorbic acid (AA) at 200 ppm plus citric acid (CA) at 100 ppm.

Actually, the increment in the umbel numbers of fennel plants due to the ascorbic and citric acid may be attributed to the stimulation effect of growth specially branching which in turn increased flowering in term of flowers (umbels) number.

\section{Effect of ascorbic and citric acid on fruit yield:}

Data in Table (3) emphasized that, generally all of the treatments had a highly effect on the fruit yield g/plant over the control in both seasons.

The weight of fruit yield g/plant, recorded a significant response (43.17 and $53.17 \mathrm{~g} /$ plant) to citric acid at 100 and 200 ppm compared to the control (39.07 g/plant) in the first season. While, in the second season citric acid at $200 \mathrm{ppm}$ had a significantly effect on fruit yield 56.07 g/plant compared to the control (41.93 g/plant).

As for the effect of ascorbic acid (AA), it was noticed in general that the plants which were treated by 100 and $200 \mathrm{ppm}$ showed significant increase in the fruit yield $\mathrm{g} / \mathrm{plant}$ in the two seasons. In the first season data were 46.40 and $62.17 \mathrm{~g} /$ plant compared to untreated plants $39.07 \mathrm{~g} /$ plant. The same trend was found in the second season i.e. fennel plants showed good response to ascorbic acid at the two rates used and produced the highest fruit yield/plant 54.03 $\mathrm{g} /$ plant for $100 \mathrm{ppm}$ and $65.90 \mathrm{~g} / \mathrm{plant}$ for $200 \mathrm{ppm}$ compared to control $41.93 \mathrm{~g} /$ plant.

These results met those of (El-Gabas, 2006) who found that spraying ascorbic acid had favorable effects on yield of sunflower. El-Zohiri (2009) found that foliar application of salicylic acid or ascorbic acid increased the yield of globe artichoke.

Spraying plants with ascorbic (AA) acid plus citric acid (CA) at all rates was found to be more effective in increasing the fruit yield $\mathrm{g} /$ plant than the solely application of each of them and the untreated plants in the two seasons. The heaviest fruit yield g/plant was recorded with (AA 200 ppm plus CA 200 $\mathrm{ppm})$, data were 72.90 and $74.13 \mathrm{~g} / \mathrm{plant}$ and followed by 68.93 and $68.00 \mathrm{~g} / \mathrm{plant}$ for (AA $200 \mathrm{ppm}$ plus CA $100 \mathrm{ppm}$ ) data were in the first and the second season, respectively.

It was easily to concluded that fennel plants attained maximum responses in fruiting by the application of the combinations of ascorbic and citric acid at the highest rate due to their promotion effect in growth traits and inducing early flowering, therefore accelerating fruiting of fennel plants before the sharp fluctuations of climate that occurred in the spring which in turn had a bad effect in fruiting of umbelliferous plants. This early flowering of fennel plants had a positive effect in umbels number/plant consequently the fruit yield/plant. So, fennel plants showed a significant increment in the yield of fruits compared to control in response to this treatment as well as the rest of the treatments.

It was easy to notice that, fruiting of fennel plants in term of fruit yield per plant was found to be associated with both the early flowering plants and the plant umbels number so, the highest plant fruit yield was obtained by the earliest flowering plants, which also have the highest number of umbels and vice versa. The application of (AA 200 ppm plus CA 200 ppm), therefor, this treatment gave the maximum increase in Indian fennel fruit yield $\mathrm{g}$ /plant over control. The increment percentages were 87 and $77 \%$ in the $1^{\text {st }}$ and $2^{\text {nd }}$ seasons, respectively as shown in Table (3).

\section{Effect of ascorbic and citric acid on essential oil content:}

\section{Essential oil percentage:}

Data in Table (4) showed that, the essential oil percentage of fennel fruits was affected by ascorbic acid (AA) and citric acid (CA) individually or in combinations in the two successive seasons. 
Table 3. Effect of ascorbic and citric acid on fruit yield (g/plant) of Foeniculum vulgare var. vulgare plants.

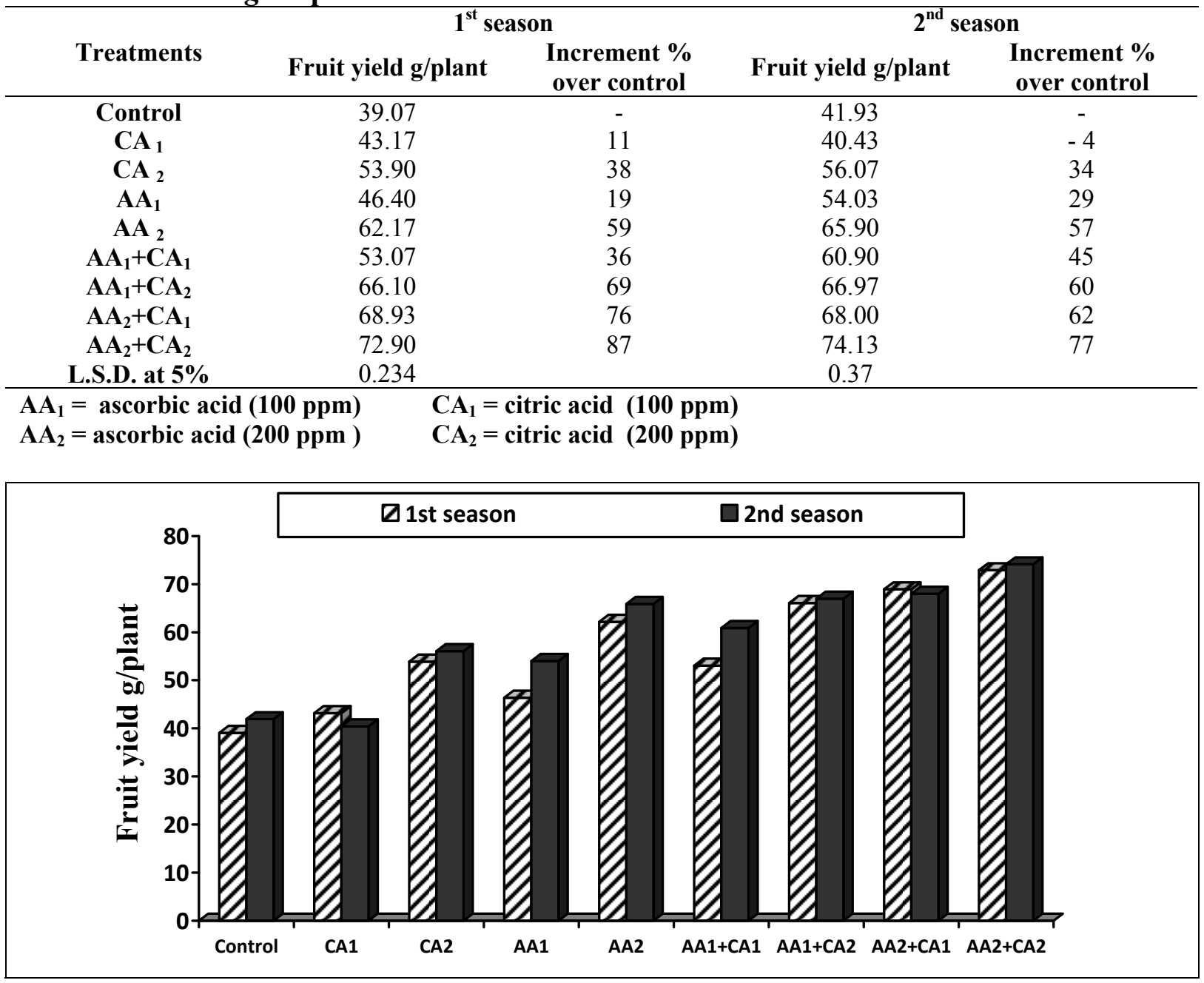

Fig. 5. Effect of ascorbic and citric acid on fruit yield g/plant of Foeniculum vulgare var. vulgare plants.

Table 4. Effect of ascorbic acid and citric acid on essential oil production of Foeniculum vulgare var. vulgare plants.

\begin{tabular}{|c|c|c|c|c|c|c|}
\hline \multirow[b]{3}{*}{ Treatments } & \multicolumn{6}{|c|}{ Essential oil production } \\
\hline & \multicolumn{3}{|c|}{$1^{\text {st }}$ season } & \multicolumn{3}{|c|}{$2^{\text {nd }}$ season } \\
\hline & $\begin{array}{c}\text { Oil } \\
\text { Percentage } \\
\%\end{array}$ & $\begin{array}{l}\text { Oil yield } \\
\text { ml/ plant }\end{array}$ & $\begin{array}{c}\text { Increment } \\
\%\end{array}$ & $\begin{array}{c}\text { Oil } \\
\text { Percentage } \\
\%\end{array}$ & $\begin{array}{l}\text { Oil yield } \\
\text { ml /plant }\end{array}$ & $\begin{array}{c}\text { Increment } \\
\%\end{array}$ \\
\hline Control & 1.51 & 0.59 & - & 1.52 & 0.64 & - \\
\hline $\mathrm{CA}_{1}$ & 1.69 & 0.73 & 24 & 1.63 & 0.66 & 03 \\
\hline $\mathbf{C A}_{2}$ & 1.98 & 1.07 & 81 & 1.90 & 1.06 & 80 \\
\hline $\mathbf{A} \mathbf{A}_{1}$ & 1.87 & 0.87 & 48 & 2.00 & 1.08 & 83 \\
\hline $\mathbf{A A}_{2}$ & 2.32 & 1.45 & 146 & 2.21 & 1.47 & 149 \\
\hline $\mathbf{A} \mathbf{A}_{1}+\mathbf{C} \mathbf{A}_{1}$ & 2.06 & 1.10 & 86 & 2.15 & 1.29 & 119 \\
\hline $\mathbf{A A _ { 1 }}+\mathbf{C A} \mathbf{A}_{2}$ & 2.30 & 1.42 & 141 & 2.36 & 1.58 & 168 \\
\hline $\mathbf{A A _ { 2 }}+\mathbf{C A} \mathbf{A}_{1}$ & 2.44 & 1.68 & 185 & 2.50 & 1.70 & 188 \\
\hline $\mathbf{A} \mathbf{A}_{2}+\mathbf{C A} \mathbf{A}_{2}$ & 2.71 & 1.98 & 236 & 2.78 & 2.06 & 249 \\
\hline L.S.D. at 5\% & 0.07 & 0.04 & & 0.05 & 0.276 & \\
\hline $\mathbf{A A}_{1}=$ ascorbic & (100 ppm) & $\mathbf{C A}_{1}=$ & id $(100$ & & & \\
\hline $\mathbf{A A _ { 2 }}=$ ascorbic & (200 ppm ) & $\mathbf{C A}_{2}=$ & acid $(200 p$ & & & \\
\hline
\end{tabular}




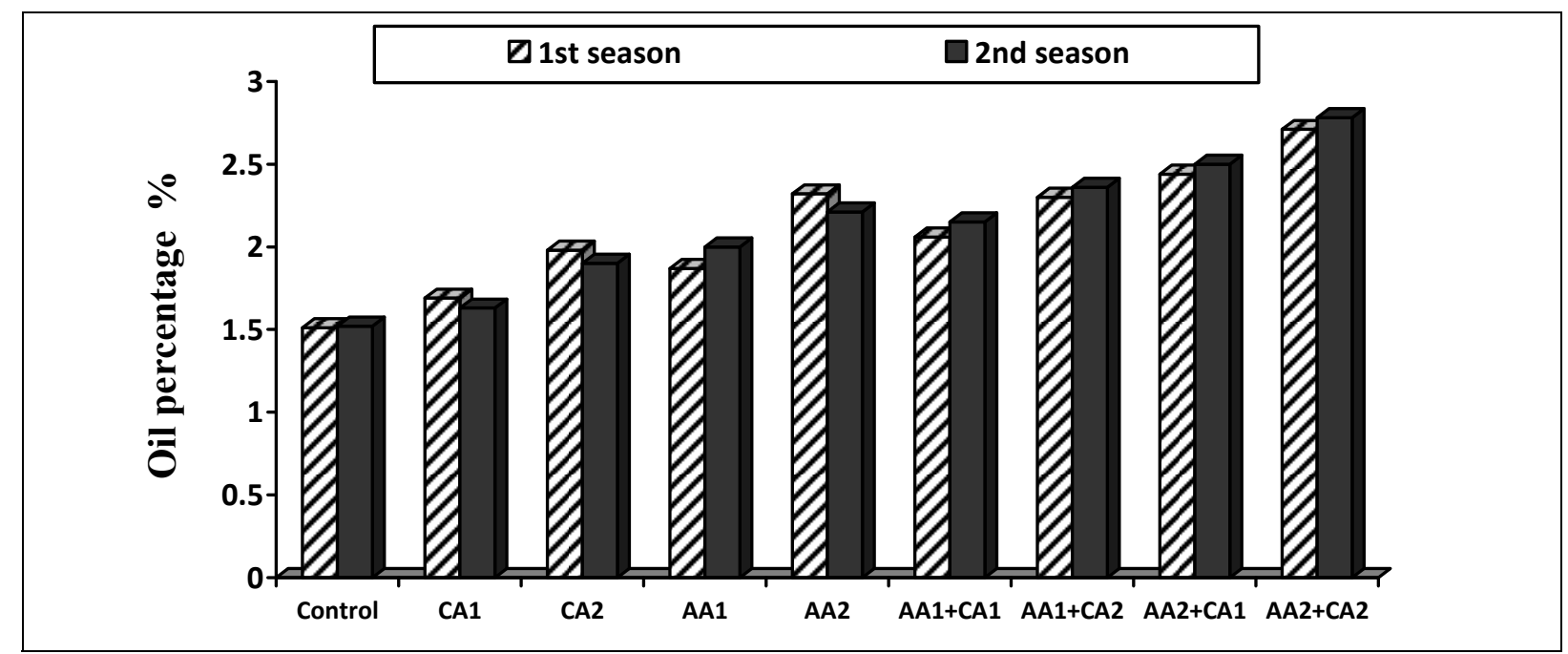

Fig. 6. Effect of ascorbic and citric acid on oil percentage \% of Foeniculum vulgare var. vulgare plants.

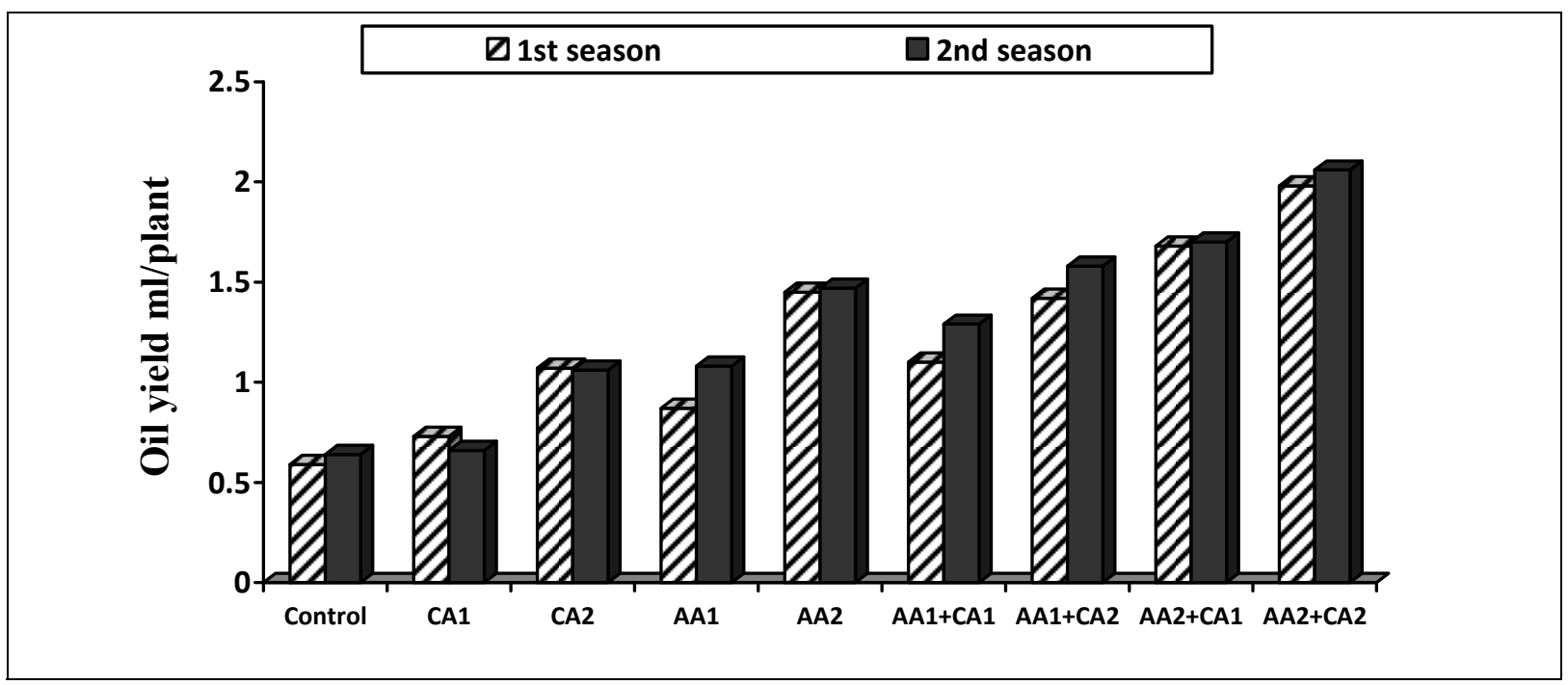

Fig. 7. Effect of ascorbic and citric acid on oil yield $\mathrm{ml} / \mathrm{plant}$ of Foeniculum vulgare var. vulgare plants

The essential oil percentage raised in both seasons as a result of treating the plants with ascorbic acid (AA) at the two rates 100 and $200 \mathrm{ppm}$. The essential oil percentage recorded an increase from $1.51 \%$ for the control to $1.87 \%$ and $2.32 \%$ due to the application of 100 and 200ppm (AA) in the first season. Also, the essential oil percentage raised from $1.52 \%$ for the control to 2.00 and $2.21 \%$ at 100 and 200 ppm (AA), respectively, in the second season.
Also, the essential oil percentage was increased by the application of citric acid (CA) at the two rates 100 and $200 \mathrm{ppm}$. In the first season the recorded values were $1.69 \%$ for $100 \mathrm{ppm}$ and $1.98 \%$ for $200 \mathrm{ppm}$ compared to the control $1.51 \%$. The same trend was recorded in the second season $1.63 \%$ and $1.90 \%$ compared to $1.52 \%$ in the control.

As for the combination treatments, treating fennel plants with ascorbic acid (AA) with citric acid (CA) significantly 
increased the essential oil percentage. The highest essential oil percentage was $2.71 \%$ in the first season and $2.78 \%$ in the second one as a result of using ascorbic acid $200 \mathrm{ppm}$ plus citric acid 200ppm compared to the untreated plants $1.51 \%$ and $1.52 \%$ in the first and the second seasons, respectively.

\section{Essential oil yield $\mathrm{ml} /$ plant:}

Table (4) presented the essential oil yield $\mathrm{ml} /$ plant, it was found that treated fennel plants with AA at 100 and 200ppm had a significant effect on oil yield $\mathrm{ml} / \mathrm{plant}$ in the two seasons. In the first season the values were 0.87 and $1.45 \mathrm{ml} /$ plant compared to control $0.59 \mathrm{ml} /$ plant, also the same treatments gave 1.08 and $1.47 \mathrm{ml} /$ plant compared to control $0.64 \mathrm{ml} /$ plant in the second season. Similar results were obtained by (Bahram, et al., 2014) noticed that, ascorbic acid significantly increase essential oils of German chamomile.

As for citric acid, it was found that treated fennel plants by citric acid (CA) at 100 and $200 \mathrm{ppm}$ had a significant effect on essential oil yield $\mathrm{ml} /$ plant in both seasons. The values were 0.73 and $1.07 \mathrm{ml} /$ plant compared to the control $0.59 \mathrm{ml} / \mathrm{plant}$ in the first season. While, in the second season only CA at $200 \mathrm{ppm}$ showed a significant effect in this concern. The value was 1.06 $\mathrm{ml} /$ plant compared to the control 0.64 $\mathrm{ml} /$ plant. These findings hold true in both seasons and were found to be in harmony with those of (Jaafari and Hadvi, 2012) on basil and (Jafari and Hadavi, 2012) on dill plants.found that treated plants with citric acid increased essential oil yield.

The positive effect of combined ascorbic acid with citric acid was pronounced. The values of oil yield $\mathrm{ml} /$ plant was greater than each of them individually. The best results 2.71 and $2.06 \mathrm{ml} /$ plant were obtained as a result of using ascorbic acid (AA) 200 ppm plus citric acid (CA) $200 \mathrm{ppm}$ in the first and the second season, respectively.

Generally, the highest increment of oil yield of fennel plant was obtained due to the application of ascorbic acid 200 ppm plus citric acid 200ppm in both season therefore, this increment in essential oil yield was logically expected as Indian fennel plants recorded a growth stimulation, early flowering, highest umbels number, highest fruit yield increment and finally the promotion of essential oil percent. This treatment increased the oil yield $\mathrm{ml} /$ plant to $236 \%$ and $249 \%$ compared to the control in the two seasons, respectively.

\section{Essential oil constituents:}

Data in Table (5) and Figs. (8-11) showed the fractionated components of the essential oil of Indian fennel plants in the second season, for the treatments of untreated plants, ascorbic acid (AA) 200 ppm, citric acid (CA) 200 ppm and, ascorbic acid (AA) 200 ppm plus citric acid (CA) 200 ppm. The obtained results confirmed that anethole and fenchone were the main components of India fennel essential oil. It was observed that anethole content was increased when using ascorbic acid (AA) at 200 ppm plus citric acid (CA) at 200 ppm, the recorded value was $80.74 \%$ and followed $77.60 \%$ in case of ascorbic acid $200 \mathrm{ppm}$ alone compared to the control $70.51 \%$. Fenchone percent increased in the control $18.22 \%$ followed by $16.04 \%$ for citric acid $200 \mathrm{ppm}$. It was found a up/down relation between anethole and fenchone, i.e. treatments positively affected anethole content up negatively affected fenchone content down.

In general, the results of this study indicated that the highest anethole content was found to associated with the early flowering and fruiting, so the combination treatment of 200ppm (AA) plus 200ppm (CA) which induce maximum early flowering and fruiting also recorded the highest anethole content.

\section{RECOMMENDATION}

It could be recommended to treat Indian fennel with ascorbic acid (AA) at $200 \mathrm{ppm}$ plus citric acid (CA) at $200 \mathrm{ppm}$ increased the vegetative growth, fruit yield, essential oil production. This treatment increased the 
Table 5. Effect of ascorbic acid and citric acid on GLC analysis of the volatile oil of Foeniculum vulgare var. vulgare plants.

\begin{tabular}{ccccccc}
\hline Treatments & $\boldsymbol{\alpha}$ - pinene & Myrcene & Fenchone & Limonene & $\mathbf{1 , 8}$ cineole & Anethole \\
\hline Control & 1.33 & 1.21 & 18.22 & 0.85 & 1.41 & 70.51 \\
$\mathbf{A A} \mathbf{2}_{2}$ & 1.29 & 2.01 & 11.21 & 0.24 & 3.06 & 77.60 \\
$\mathbf{C A}_{2}$ & 1.22 & 1.12 & 16.04 & 0.84 & 5.77 & 76.98 \\
$\mathbf{A A}_{\mathbf{2}}+\mathbf{C A}_{\mathbf{2}}$ & 1.97 & 0.83 & 11.06 & 1.30 & 3.95 & 80.74 \\
\hline
\end{tabular}

$\mathrm{AA}_{2}=$ ascorbic acid (200 ppm) $\quad \mathrm{CA}_{2}=$ citric acid (200 ppm)

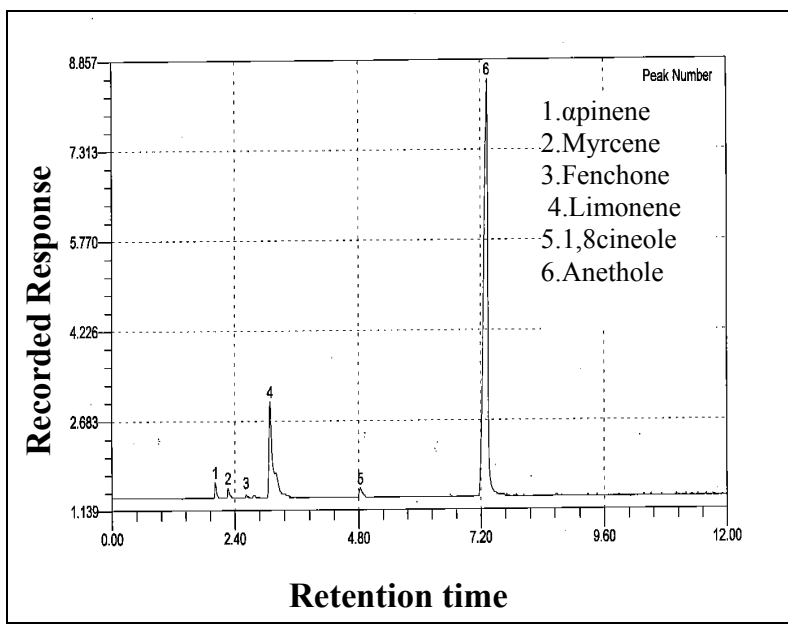

Fig. 8. (GLC) chromatogram of Indian fennel essential oil (control).

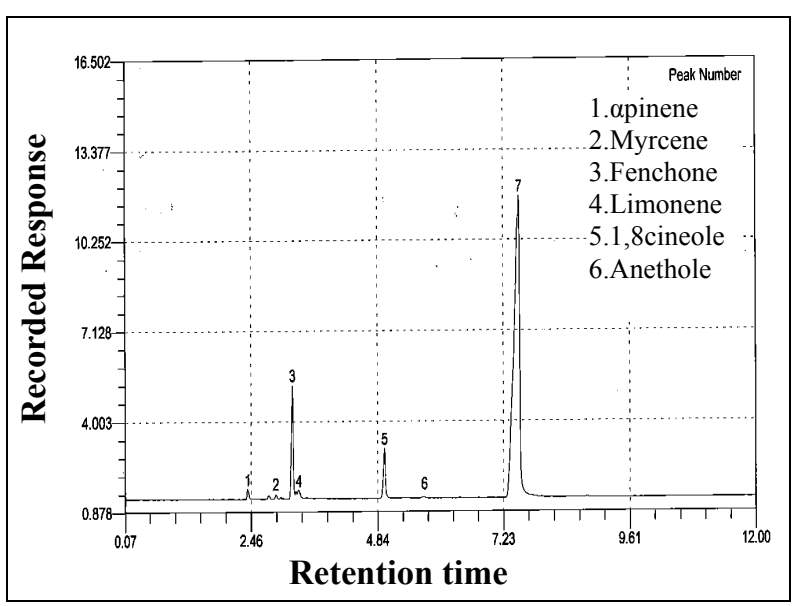

Fig. 10. (GLC) chromatogram of Indian fennel essential oil (CA2).

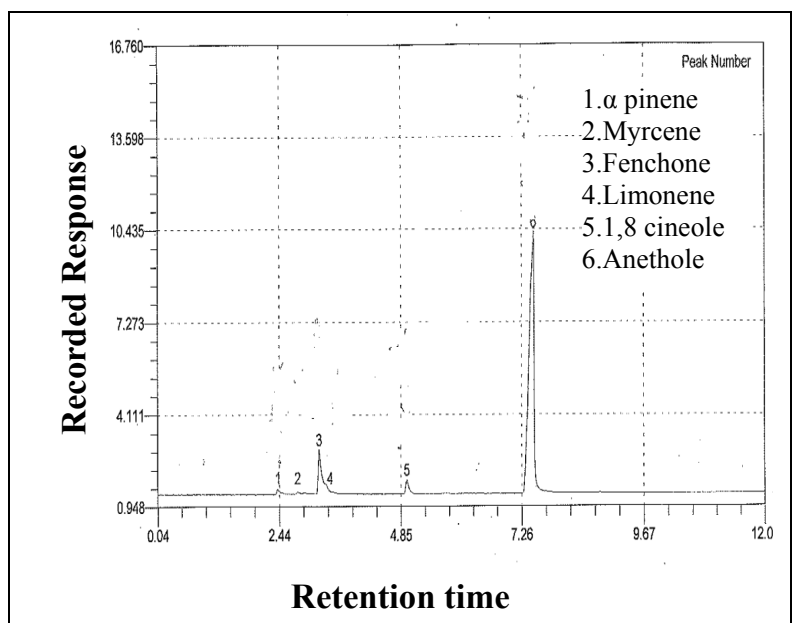

Fig. 9. (GLC) chromatogram of Indian fennel essential oil (AA2).

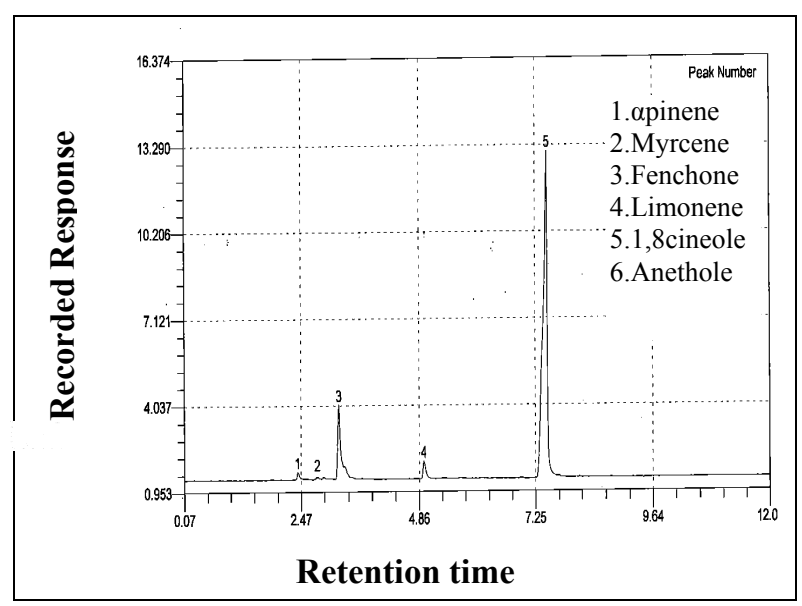

Fig. 11. (GLC) chromatogram of Indian fennel essential oil (CA2+AA2). 


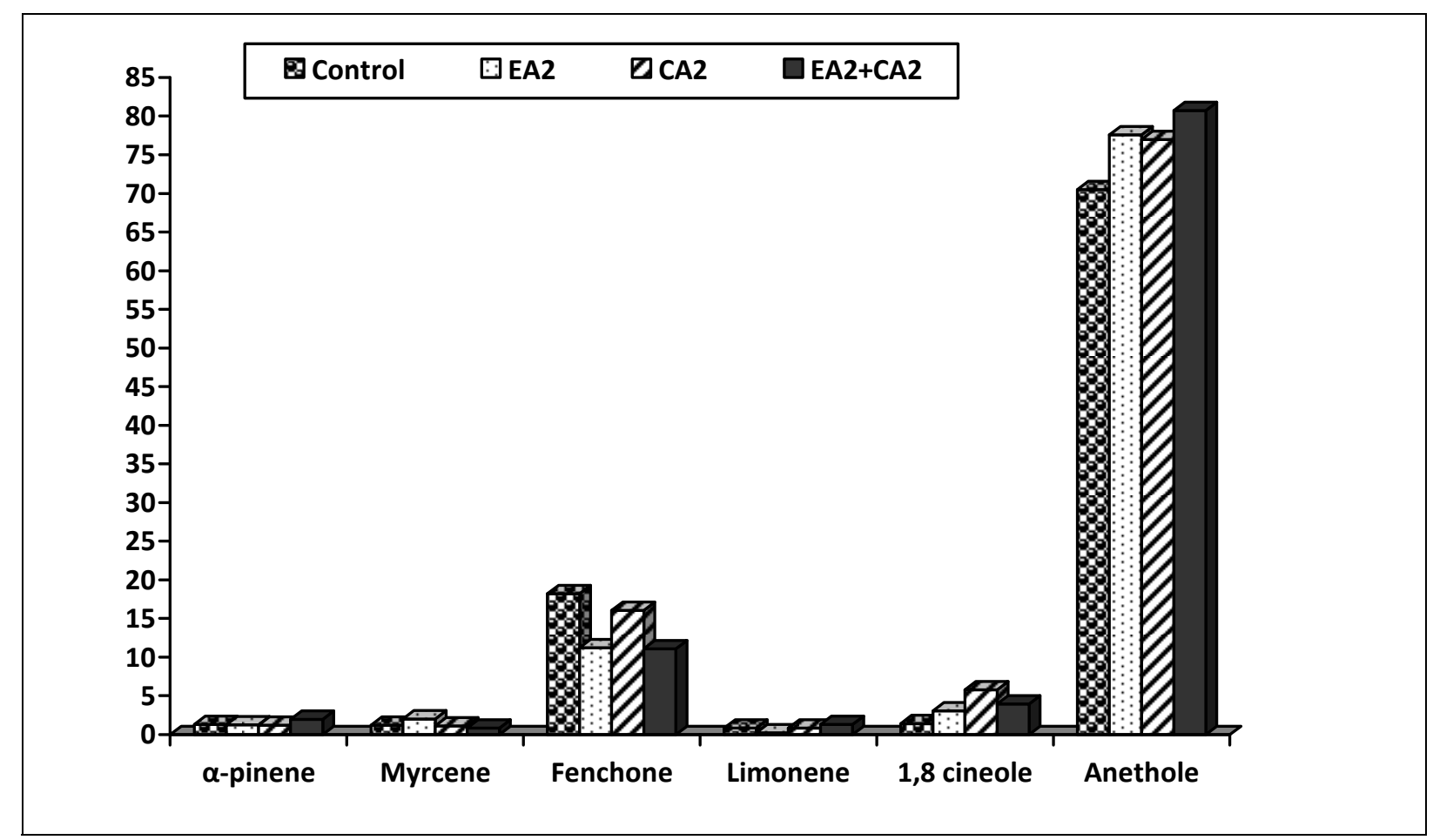

Fig. 12. Effect of ascorbic and citric acid on GLC analysis of the volatile oil of Foeniculum vulgare var. vulgare plants.

anethole content and decreased the fenchone content. Also this treatment produced the least time to flowering.

\section{REFERENCES}

Abdel Aziz, Nahed G.; Taha, L.S.; Ibrahim, Soad M.M. (2009). Some studies on the effect of putrescine, ascorbic acid and thiamine on growth, flowering and some chemical constituents of gladiolus plants at Nubaria. Ozean J. App. Sci., 2(2):169179.

Bahram, R.; Ranjbar1, S.S. and Omid, A. (2014). Growth and essential oil responses of german chamomile to thiamine and ascorbic acid. Pharmacology and Life Sciences Bull. Env. Pharmacol. Life Sci., 3(7):51-53.

Blokhina, O.; Virolainen, E. and Fagerstedt, K.V. (2003). Antioxidant, oxidative damage and oxygen deprivations stress: A Review. Ann. Bot., 91:179-194.

British Pharmacopeia (1963). Determination of Volatile Oil in Drugs. The Pharamaceutical Press London.
Bunzen, J.N.; Guchard, J.; Labbe, P.; Sperinnet, P.J. and Trenchant, J. (1969). Practical Manual of Gas Chromatography. J. Trenchant Ed., ElSeiver Publ. Comp., Amsterdam, London.

Carina, B.; Mario, D.T. and Patricia, L.C. (2006). The role of ascorbic acid in the control of flowering time and the onset of senescence. Journal of Experimental Botany, 57(8):1657-1665.

Cavaleiro, C.M.F.; Roque, O.L. and Proenca da Cunha, A. (1993). Contribution for the characterization of Portuguese fennel chemotypes. Journal Essential Oil Research, 5:223-225.

Diaaz-Maroto, M.C.; Pea rez-Coello, M.S.; Esteban, J. and Sanz, J. (2006). Comparison of the volatile composition of wild fennel samples (Foeniculum vulgare Mill.) from Central Spain. J. Agric. Food Chem. 54:6814-6818.

Dobhal, D.P.; Gergan, J.T. and Thayyen, R.J. (2004). Recession and morphogcometrical 
changes of Dokriani glacier (1962-1995), Garhwal Himalaya, India. Current Science, 86:692-696.

El-Gabas, N.M.M. (2006). Physiological Studies on The Effect of Ascorbic Acid and Micronutrients on Sunflower Plants Grown Under Salinity Stress. M.Sc. Thesis (Botany), Fac. Sci., Al-Azhar Univ.

El-Kobisy, D.S.; Kady, K.A.; Medani, R.A. and Agamy, R.A. (2005). Response of pea plant (Pisum sativum L.) to treatment with ascorbic acid. Egypt. J. Appl. Sci., 20:36-50.

El-Quesni, F.E.M.; Abd El-Aziz, N.G. and Magda, M.K. (2009). Some studies on the effect of ascorbic acid and $\alpha-$ tocopherol on the growth and some chemical composition of Hibiscus rosasinensis L. at Nubaria. Ozean J. App. Sci., 2(2):159-167.

El-Zohiri, S.S.M. (2009). Role of the salicylic and ascorbic acid on the control of growth, flowering and yield of Globe Artichoke. Annals of Agric. Sci., Moshtohor, 47(3):393-402.

Farahat, M.M.; Ibrahim, Soad M.M.; Taha, L.S. and El-Quesni, Fatma E.M. (2007). Response of vegetative growth and some chemical constituents of Cupressus sempervirens $\mathrm{L}$. to foliar application of ascorbic acid and zinc at Nubaria. World J. of Agric. Sci., 3(3):282-288.

Hanafy A.A.H. (1996). Physiological studies on tipburn and nitrate accumulation in lettuce plants. J. Agric. Sci., Mansoura Univ., 21:3971-3994.

Hendawy, S.F. and Ezz El-Din, A.A. (2010). Growth and yield of Foeniculum vulgare var.azoricum as influenced by some vitamins and amino acids. Ozean J. App. Sci., 3(1): 113-123.

Hoftman, E. (1967). Chromatography. Reinhold Pub. Corp., $2^{\text {nd }}$ Ed. p. 208-515.

Ishikawa, T.; Dowdle, J. and Smirnoff, N. (2006). Progress in manipulating ascorbic acid biosynthesis and accumulation in plants. Physiologia Plantarum, 126:343-355.

Jaafari, N. and Hadavi, E. (2012). Growth and essential oil yield of Basil (Ocimum basilicum L.) as affected by foliar spray of citric acid and salicylic acid. Zeitschrift fur Arzni-und Gewurzpflanzen, 7(2):80-83.

Jaafari, N. and Hadavi, E. (2012). Growth and essential oil yield of dill (Anethum graveolens) as affected by foliar sprays of citric acid and malic acid. Acta Horticulturae, 955:287-290.

Kotchoni, S.O.; Larrimore, K.E.; Mukherjee, M.; Kempinski, C.F. and Barth, C. (2009). Alterations in the endogenous ascorbic acid content affect flowering time in Arabidopsis. Plant Physiol., 149:803-815.

Mahdi, F.; Baki, H.B. and Baratali, G. (2011). Influence of Global Climate Change on, Growth Stage and Production of Secondary Chemicals in Medicinal and Aromatic Plants. J. Appl. Environ. Biol. Sci., 1(7) 115-125.

Marotti, M.; Dellacecca, V.; Piccaglia, R.; Giovanelli, E.; Palevitch, D. and Simon, J.E. (1993). Agronomic and chemical evaluation of three varieties of Foeniculum vulgare Mill. Acta Horticulture, 331:63-69.

Mirzajani, Z. (2013). The Effect of Foliar Application of Citric Acid and Salicylic Acid on Morphological and Physiological Traits of Annuals Sweet Basil (Ocimum basilicum L.). Department of Horticulture, Karaj Branch, Islamic Azad University, Karaj.

Pastori, G.M.; Kiddle, G.; Antoniw, J.; Bernard, S.; Veljovic-Jovanovic, S.; Verrier, P.J.; Noctor, G. and Fover, C.H. (2003). Leaf vitamin C contents modulate plant defense transcripts and regulate genes that control development through hormone signaling. Plant Cell, 15:939-951. 
Piccaglia, R. and Marotti, M. (1993). Characterization of several aromatic plants grown in northern Italy. Flavour Fragrance Journal, 8:112-115.

Snedecor, G.W. and Cochran, W.G. (1980). Statistical Methods. $6^{\text {th }}$ Ed. Iowa State Univ. Press, Ames, Iowa, USA., 507 pp.

Silva, J.A.T. (2003). The cut flower postharvest consideration. Journal of Biological Sciences, 3(4):406-442.

Tarraf, S.A.; El-DIN, K.M.G. and Balbaa, L.K. (1999). The response of vegetative growth, essential oil of lemongrass to foliar application of ascorbic acid, micotinamid and some micronutrients. Arab. Universities J. Agric. Sci., 7:247259.

Wills, R.; Lee, T.; Graham, D.; McGlasson, W. and Hall, E. (1981). Postharvest. An Introduction to the Physiology and Handling of Fruit and Vegetables. Willing ford: CAB International.

$$
\begin{aligned}
& \text { تخفيف التأثير الضار للتغيرات المناخية بتبكير النمو والإزهار للشمر } \\
& \text { سلوى سمير صالح عوض الله و سعاد محمد محمود سالم } \\
& \text { قسم النباتات الطبية و العطرية، مركز البحوث الزر اعية، الدقي، مصر. }
\end{aligned}
$$

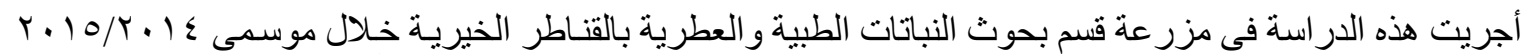

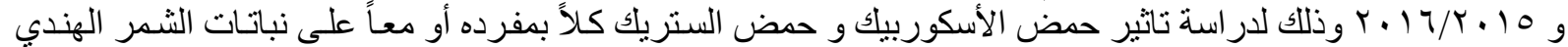

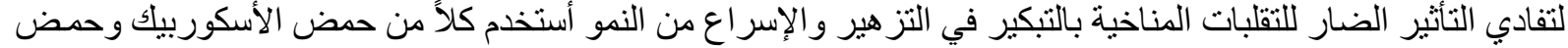

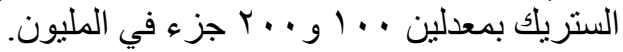

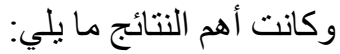

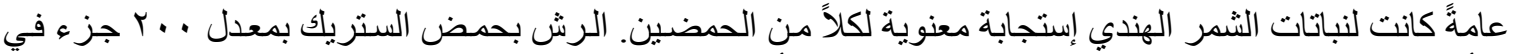

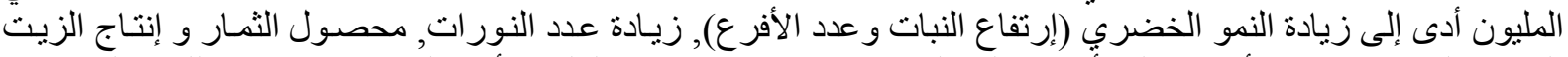

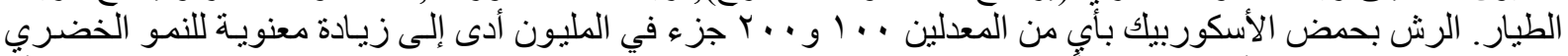

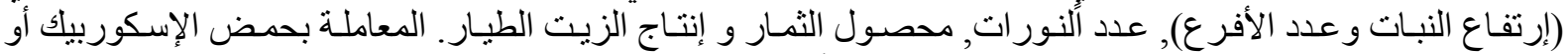

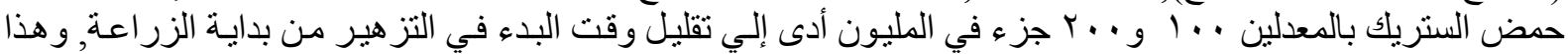

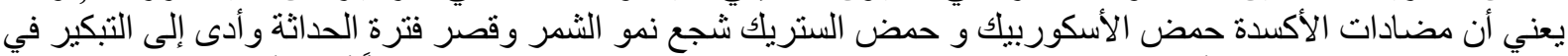

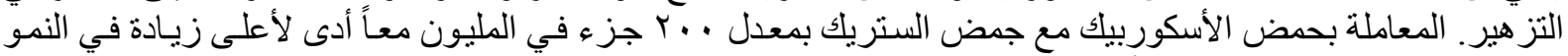

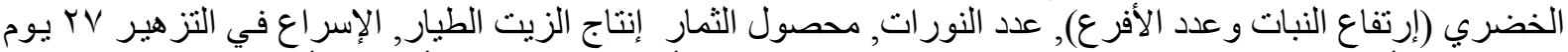

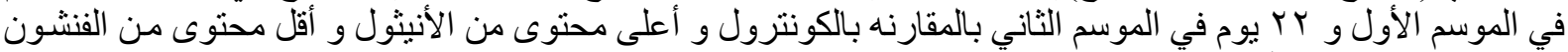

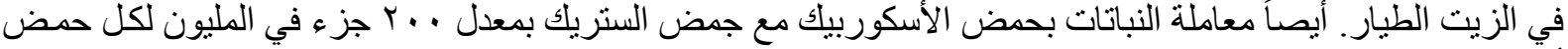

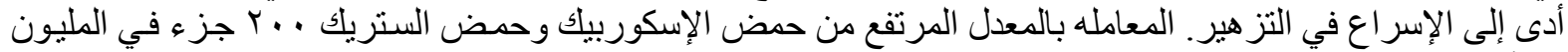

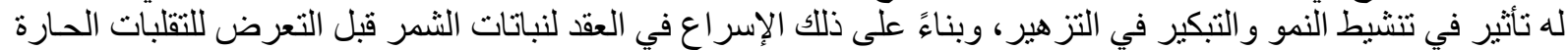
التي تحدث في الربيع أثناء فترة عقد الثمار لنباتات العائلة الخيمية. 
